\title{
Endophytic bacteria associated with rice roots from suboptimal land as plant growth promoters
}

\author{
NUR PRIHATININGSIH ${ }^{1, \boldsymbol{\iota}}$, HERU ADI DJATMIKO ${ }^{1}$, PUJI LESTARI $^{2}$ \\ ${ }^{1}$ Faculty of Agriculture, Universitas Jenderal Soedirman. J1. Dr. Soeparno No. 61, Purwokerto Utara, Banyumas 53123, Central Java, Indonesia. \\ Tel./fax.: +62-281-638791, `email: nur.prihatiningsih@unsoed.ac.id \\ ${ }^{2}$ Faculty of Mathematics and Natural Sciences, Universitas Jenderal Soedirman. Jl. Dr. Soeparno No. 61, Purwokerto Utara, Banyumas 53123, Central \\ Java, Indonesia
}

Manuscript received: 16 November 2020. Revision accepted: 28 December 2020.

\begin{abstract}
Prihatiningsih N, Djatmiko HA, Lestari P. 2021. Endophytic bacteria associated with rice roots from suboptimal land as plant growth promoters. Biodiversitas 22: 432-437. Endophytic bacteria directly promoted plant growth and undirectly control the pathogens. This research was aimed to evaluate endophytic bacteria associated with rice root and their activity to promote plant growth and to control rice diseases. The study was conducted at the Laboratorium of Plant Protection and experimental farm Faculty of Agriculture Jenderal Soedirman University, from April to August 2020. The endophytic bacterial from suboptimal land were evaluated for promoting plant growth with soaking seed before seedling and spraying them at 10, 20, and 30 days after transplanting. The experiment was arranged with six replications and four treatments namely control (untreated endophytic bacteria) SM1 (endophytic bacteria isolate from Somagede); SB1 and SB3 (from Sumbang). Xanthomonas oyzae pv. oryzae was nature inoculation because the experiment location is in the endemic category of bacterial leaf blight. The variables observed were the plant growth components i.e plant height, number of tillers, number of panicles, incubation period, disease intensity, infection rate and effectiveness control. The result of this research shows that endophytic bacteria from Somagede (SM1) is the best to enhance plant height and number of tillers, and suppress disease intensity, and delay of incubation period.
\end{abstract}

Keywords: Endophytic bacteria, plant growth, rice, Xanthomonas oryzae pv. oryzae

\section{INTRODUCTION}

Endophytic bacteria living in plant tissue are nonpathogens, and produce compounds that help plant growth. Endophytic bacteria reach sufficient populations and are capable of producing plant growth-promoting compounds such as IAA (indole acetic acid) and gibberellins. Endophytic bacteria are associated with plants to help the absorption of nutrients because they are able to dissolve phosphate into a form available to plants (Adesemoye et al. 2009; Glick 2012; Dawwam et al. 2013). They are able to produce siderophore to chelate iron into iron-siderophore bonds available to plants. Like rhizobacteria, according to Kesaulya et al. (2015), they are able to act as biostimulants (produce phytohormones), biofertilizers (to help absorb nutrients for plants), and bioprotectants (suppress disease). Endophytic bacteria indirectly affect plants as a bioprotectant or biocontrol to several plant diseases (Berg et al. 2005; Muthukumar et al. 2017).

The major mechanism of endophytic bacteria in plants are (i) to assist nutrient availability and uptake (ii) to enhance stress tolerance (iii) to provide disease resistance (Ryan et al. 2008; Hamilton et al. 2012). Meanwhile, induced disease resistance activities are allied with the abilities to produce secondary metabolites, such as antibiotics or chitinase (Christina et al. 2013; Pieterse et al. 2014; Wang et al. 2014). Due to their beneficial functions such as plant growth promotion and disease control, endophytes can be used in the form of bio-formulations (seed treatment, soil application, and seedling dip) in agriculture.

Bacterial leaf blight caused by Xanthomonas oryzae pv. oryzae (Xoo) is an important disease because it causes damage to leaves and can cause yield losses of up to $74 \%$ in Southeast Asia (Sarra et al. 2010). The severity of the disease depends on the virulence of the bacterial isolate which causes two primary symptoms, namely blight (seed blight) and crackle (wilt phase). During the blight phase bacteria enter through wounds or water pores on the edges and tops of the leaves causing systemic symptoms, resulting in irregular yellow wet spots, with wavy edges, irregular leaves and spots starting from the edge near the tip of the leaf (Singh et al. 2013). Xoo is a rod-shaped bacteria $0.55-0.75 \times 1.35-2.17 \mu \mathrm{m}$, with a single polar flagellum, not spore-forming, motile, single or paired, and sometimes chained, a Gram-negative, the colony is light yellow. More than 30 races were found with sub-groups within the species (Furutani et al. 2009).

Efforts to improve plant growth and control bacterial leaf blight have been carried out by using antagonistic bacteria from the rice rhizosphere, namely Bacillus subtilis B1 in an organic fertilizer formula (Djatmiko et al. 2017). The leaf blight is classified as vascular disease, so it is difficult to control only with antagonistic bacteria. It is necessary to do this with endophytic bacteria that can infect the tissue, and interact directly with the Xoo. The research previously showed control of bacterial leaf blight on-screen house with the effectiveness of more than $60 \%$ 
(Prihatiningsih et al. 2020a). Suboptimal land development for agriculture is generally faced with several problems, including high soil acidity and toxicity of $\mathrm{Fe}$ and $\mathrm{Al}$ as well as deficiency of nutrients $\mathrm{N}, \mathrm{P}, \mathrm{K}, \mathrm{Ca}$, and $\mathrm{Mg}$. Therefore, improvements need to be done to the condition of soil biology and chemistry, using endophytic bacteria. Suboptimal land spread on the embankment of the river, the lower part of the river terraces, alluvial depression, plain fluvial marine, and peat (Sirappa and Titahena 2014). The specification of this research is the application of endophytic bacteria associated with rice roots as antagonistic to improve plant growth. This research aimed to evaluate endophytic bacteria associated with rice root and their activity to promote the plant growth directly and to control rice bacterial leaf blight indirectly.

\section{MATERIALS AND METHODS}

\section{Preparations of endophytic bacterial associated of rice root (EBARr) from suboptimal land}

Endophytic bacteria from root samples of healthy rice plants from suboptimal land around Banyumas were prepared from the results of previous research isolation. Initially, 21 isolates were obtained and then selected to produce nine potential endophytic bacterial isolates. Then the nine endophytic bacterial isolates were tested in vitro for inhibition against Xoo and in the screen house, the endophytic bacteria were tested to suppress bacterial leaf blight (Prihatiningsih et al. 2020a). The results of the two series of studies were 3 isolates that were able to suppress disease, namely SM1 (Somagede 1 isolate), SB1 (Sumbang 1), and SB3 (Sumbang 3). Furthermore, in this study, the three endophytic bacteria were tested in rice fields.

\section{The evaluation of endophytic bacterial associated of rice root (EBARr) to promote plant growth with observed of promoter component \\ Hydrogen Cyanide (HCN) production test}

The nine endophytic bacterial isolates were tested as $\mathrm{HCN}$ producers. The paper disc was immersed in a $0.5 \%$ picric acid solution in a $2 \%$ sodium carbonate solution, placed on a NB medium containing $0.44 \%$ glycine. Then, it was affixed to the test tube wall. Endophytic bacteria producing HCN gas are shown by the change of the paper disc color from yellow to brown (Reetha et al. 2014).

\section{The siderophore production test}

The siderophore production test was carried out with SD-CASA medium, dark blue, $2 \%$ agar $\mathrm{w} / \mathrm{v}$ in order to be added. As much as $10 \mathrm{ml}$ of CAS-blue agar was the basis of the plate. After being solidified, it was coated with $6 \mathrm{ml}$ of YPGA (yeast extract peptone glucose agar) medium. Then, the plate was incubated overnight at $32^{\circ} \mathrm{C}$, Ten $\mu$ of supernatant endophytic bacteria was dropped on a paper disc, forming an orange or pink zone (Hu and $\mathrm{Hu} 2011$ ).

\section{Testing IAA production}

Endophytic bacteria isolates were grown on slanted NA medium with and without L-Tryptophan (0.5\%). After 2 days of incubation at room temperature then, $100 \mu \mathrm{l}$ of Salkowski reagent A was dropped $\left(2 \% 0.5 \mathrm{FeCl}_{3}\right.$ in $35 \%$ $\mathrm{HCLO}_{4}$ solution). Colonies producing IAA show a change in color to pink (Mohite 2013).

\section{The phosphate solubility activity test}

The phosphate solubility activity test was assessed qualitatively using potato-dextrose yeast extract agar (PDYA)-CaP. Each bacterial culture was scratch inoculated in PDYA-CaP medium at 4 places, incubated at $28 \pm 2^{\circ} \mathrm{C}$ for 10 days. The clear zone shows that the endophytic bacteria is capable of phosphate solubility (Khan et al. 2009).

\section{Resistance test of isolates to antibiotics}

The resistance test of isolates against antibiotics was carried out by growing endophytic bacteria on the NA medium by means of the pour plate method, dipping the sterile paper disc pieces in antibiotics after draining and then placing them on the bacterial medium, incubated for 24 hours. If a clear zone is formed, it means that the endophytic bacteria is sensitive to these antibiotics, while those that do not form a clear zone mean that they are resistant to these antibiotics (Yasmin et al. 2009).

\section{Testing of endophytic bacteria to promote plant growth}

Observation of the growth components of rice plants is intended as a direct effect of endophytic bacteria on plants, including plant height and the number of tillers, number of panicles. The study was conducted with a completely randomized block design with 4 treatments and 6 replications. The treatments were controlled (untreated endophytic bacteria), B: SM1 (endophyte bacteria Somagede 1 isolate), C: SB1 (endophytic bacteria Sumbang 1 isolate), and D: SB3 (endophytic bacteria Sumbang 3 isolate). The treatment of endophytic bacteria was started by soaking the seeds before seedling for 1 night, followed by spraying the plants at 20,30, and 40 days after planting. The observed variables were plant height, number of tillers, and number of panicle.

\section{The activity of EBARr as biocontrol of bacterial leaf blight}

Endophytic bacteria as disease control as an indirect effect is carried out in bacterial leaf blight endemic areas and uses varieties that are susceptible-tolerant to bacterial leaf blight, namely Ciherang. Treatment and design such as testing on plant growth. The endophytic bacterial density was $10^{9} \mathrm{cfu} / \mathrm{mL}$. Variables observed were components of the pathosystem (incubation period, disease intensity, infection rate, control effectiveness). Observation of disease intensity using the formula $\mathrm{DI}=\Sigma(\mathrm{n} \mathrm{xv}) /(\mathrm{Z} \mathrm{xN}) \mathrm{x}$ $100 \%, \mathrm{DI}=$ disease intensity, $\mathrm{n}=$ number of plants from each scale category, $\mathrm{v}=$ scale category, $\mathrm{N}=$ number of plants observed, $\mathrm{Z}=$ highest category value. Xoo's attack category is: $0=$ healthy, $1=$ damage scale $1-5 \%, 3=$ damage scale $6-12 \%, 5=$ damage scale $13-25 \%, 7=$ damage scale $26-50 \%, 9=$ scale $51-100 \%$ damage (Djatmiko et al. 2011). The rate of infection is calculated based on the proportion of diseased tissue obtained from the value of disease intensity with the van der Plank 
formula (1963), Xt $=$ Xo. $\mathrm{e}^{\mathrm{rt}}$, where $\mathrm{Xt}=$ proportion of diseased intensity at time $\mathrm{t}$ and $\mathrm{Xo}=$ proportion of diseased intensity at initial time, $\mathrm{e}=$ logarithmic number, $\mathrm{r}=$ infection rate and $t=$ interval of observation time. Because of the bacterial leaf blight is a simple interest disease, calculate $r=2,3 / t(\log 1 /(1-\mathrm{Xt})-\log 1 /(1-\mathrm{Xo})$ unit/day.

\section{Data analysis}

Data at the laboratory experiment were analyzed by descriptive methods and then communicated and compared to references. Data from experimental exfarm were analyzed by ANOVA, if the effect is significant, it's continued with LSD 5\%.

\section{RESULTS AND DISCUSSION}

Based on the characterization of endophytic bacteria in previous studies and by heating treatment in an oven at $80^{\circ} \mathrm{C}$ for 20 minutes of the suspension of rice root endophytic bacteria in the 1 st dissolution, most of the endophytic bacteria obtained showed Gram-positive, in the form of short rod shape - rod shape, forming endospores, then grouped into the genus Bacillus sp. (Gordon et al. 1973; Prihatiningsih et al. 2020a).

\section{Plant growth promoter component of EBARr}

The component of plant growth promoter showed from nine endophytic bacteria that could produce $\mathrm{HCN}$, siderophore, IAA, and phosphate solubility as qualitative tests (Table 1). The various respond of four assays showed the relative of qualitative. Figure 1 showed $\mathrm{HCN}$ production from nine endophytic bacteria before reaction to produce $\mathrm{HCN}$ (A) with yellow and (B) after production $\mathrm{HCN}$, the paper disc become brown.

Endophytic bacteria are able to stimulate plant growth by observing plant growth-promoting components, namely bacteria as a producer of HCN, siderophore, IAA, and as a phosphate solubility (Table 1). The response of plant growth promoter components was varied from the nine isolates of endophytic bacteria that were tested as a result of the selection from the first year. Bacteria that are able to produce HCN show that these bacteria are capable of being biocontrol. This is because the role of $\mathrm{HCN}$ is to inhibit the proliferation or multiplication of pathogens, stimulate the formation of root hairs, thereby help to increase nutrient absorption (Olanrewaju et al. 2017).

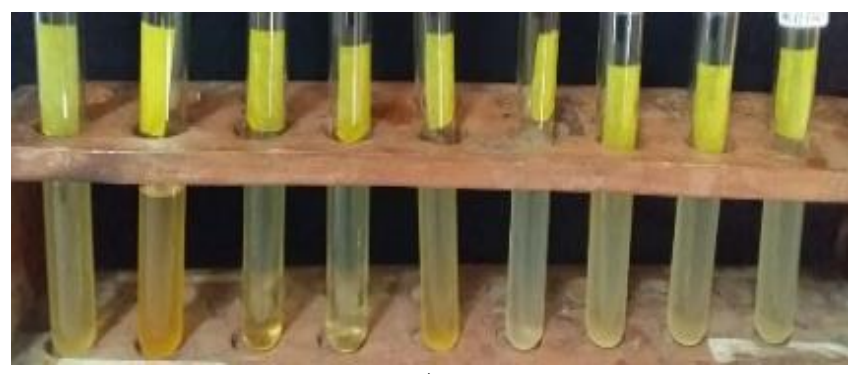

A

Figure 1. HCN production test of the nine endophytic bacteria (A) Before reaction and (B) After reaction as HCN production with brown color of paper
Figure 2 showed the six endophytic bacteria produced siderophore with orange zone except for the Kr7, SR1 dan SB3, the medium still blue. The bacterial siderophore test formed an orange zone indicating that the type of siderophore was hydroxamate (Ahmed and Holmstrom 2014; Prihatiningsih et al. 2017). Siderophores are low molecular weight compounds produced by bacteria and are capable of chelating iron into a form of siderophore- $\mathrm{Fe}^{3+}$ bonds available to plants. This siderophore is also one of the biocontrol mechanisms by binding to $\mathrm{Fe}^{3+}$ so the pathogen is limited in the need for $\mathrm{Fe}^{3+}$. Therefore, the pathogen is inhibited from reproducing to reach the rhizosphere due to iron deficiency (Glick 2012; Prihatiningsih et al. 2017).

The endophytic bacteria were able to produce IAA which was marked with pink color in the endophytic bacteria culture which was dripped with Salkowski reagent (Figure 3). This indicates that endophytic bacteria are capable of producing the plant hormone IAA. Quantitative analysis of IAA production has conducted that SR7 and SB1 isolate were active at 79.33 and $75.88 \mathrm{ppm}$ respectively (Prihatiningsih et al. 2020a). IAA functions for cell division and elongation stimulates seed and tuber germination increases the rate of xylem development and root development. IAA also functions as a vegetative growth controller, initiating the formation of adventitious and lateral roots, so that plant growth is better (Glick 2012).

Table 1. Plant growth components of nine rice root endophytic bacteria

\begin{tabular}{ccccc}
\hline $\begin{array}{c}\text { Isolate } \\
\text { code }\end{array}$ & $\begin{array}{c}\text { HCN } \\
\text { production }\end{array}$ & $\begin{array}{c}\text { Siderophore } \\
\text { production }\end{array}$ & $\begin{array}{c}\text { IAA } \\
\text { production }\end{array}$ & $\begin{array}{c}\text { Phosphate } \\
\text { solubility }\end{array}$ \\
\hline Kr4 & + & ++ & + & + \\
Kr5 & + & + & + & + \\
Kr7 & + & - & - & - \\
SR1 & + & - & + & + \\
SR5 & + & + & + & + \\
SR7 & + & ++ & + & + \\
SM1 & + & ++ & + & ++ \\
SB1 & + & + & ++ & + \\
SB3 & + & - & +++ & ++ \\
\hline
\end{tabular}

Note: + : produce; ++ and +++ : produce with more color (IAA) ++ : more strong of produce siderophore and phosphate solubility, -: unproduced; Kr: Karangwangkal, SR: Serayu, SM: Somagede, SB: Sumbang

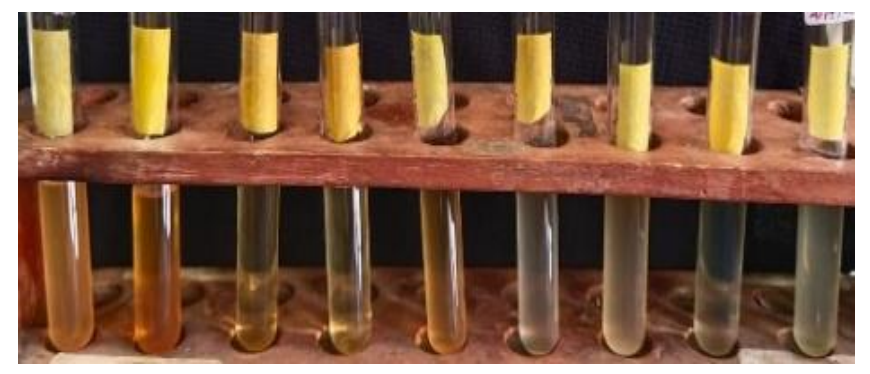

B 
The ability of endophytic bacteria as a phosphate solubility is shown by a positive reaction in Table 2 and Figure 3, with the formation of a clear zone. Solubilization of different forms of phosphate by endophytic bacteria associated with maize can be increasing its availability for plants to promote plant growth and increase the yield (Mugiastuti et al. 2020). The ability of bacteria as a phosphate solubility helps to provide nutrients available for plants because the phosphate present in the soil in a form that is not available to plants becomes available (Olanrewaju et al. 2017).

The resistance of endophytic bacteria to antibiotics (Tab;e 2, Figure 3) is very important as a pathogen biocontrol mechanism because it is exposed to many microorganisms that produce various antibiotics in the soil. Antibiotic-resistant endophytic bacteria will be able to survive so that they are able to compete in space and become antagonistic to pathogens (Ulloa-Ogaz et al. 2015). Isolates that are resistant to antibiotics as shown in Figure 3. SR7 isolates are resistant to Rifampicin antibiotics which are characterized by no zone formation, meaning that the growth of SR7 endophytic bacteria still occurs around the antibiotic On the other hand, the SR5 isolate was not resistant or sensitive to the Kanamycin antibiotic which was indicated by the formation of a clear zone around the filter paper treated with the Kanamycin antibiotic, meaning that there was no growth around the antibiotic. This is in accordance with the opinion of Yasmin et al. (2009) that the IAR test is needed to identify the endophytic bacteria resistant or sensitive to antibiotics. IAR can also be used to genotypically identify bacterial species.

Table 2. Intrinsic antibiotic resistance (IAR) test of rhizobacterial isolates

\begin{tabular}{lcccc}
\hline & \multicolumn{2}{c}{ Rifampicin } & \multicolumn{2}{c}{ Kanamycin } \\
\cline { 2 - 5 } Isolate & Reaction & $\begin{array}{c}\text { Diameter of } \\
\text { zone }(\mathbf{m m})\end{array}$ & Reaction & $\begin{array}{c}\text { Diameter of } \\
\text { zone (mm) }\end{array}$ \\
\hline Kr4 & - & 4 & - & 8 \\
Kr5 & - & 4 & - & 8 \\
Kr7 & - & 4 & - & 8 \\
SR1 & + & 0 & + & 0 \\
SR5 & - & 5 & - & 8 \\
SR7 & + & 1 & - & 6 \\
SM1 & - & 6 & - & 8 \\
SB1 & - & 7 & - & 9 \\
SB3 & + & 1 & - & 7 \\
\hline
\end{tabular}

Note: + : resistance $=$ not zone, very small $(1 \mathrm{~mm})$, -: sensitive: zone formed. Not zone: antibiotic resistance $(+)$ means that be still growing in the medium with the antibiotic
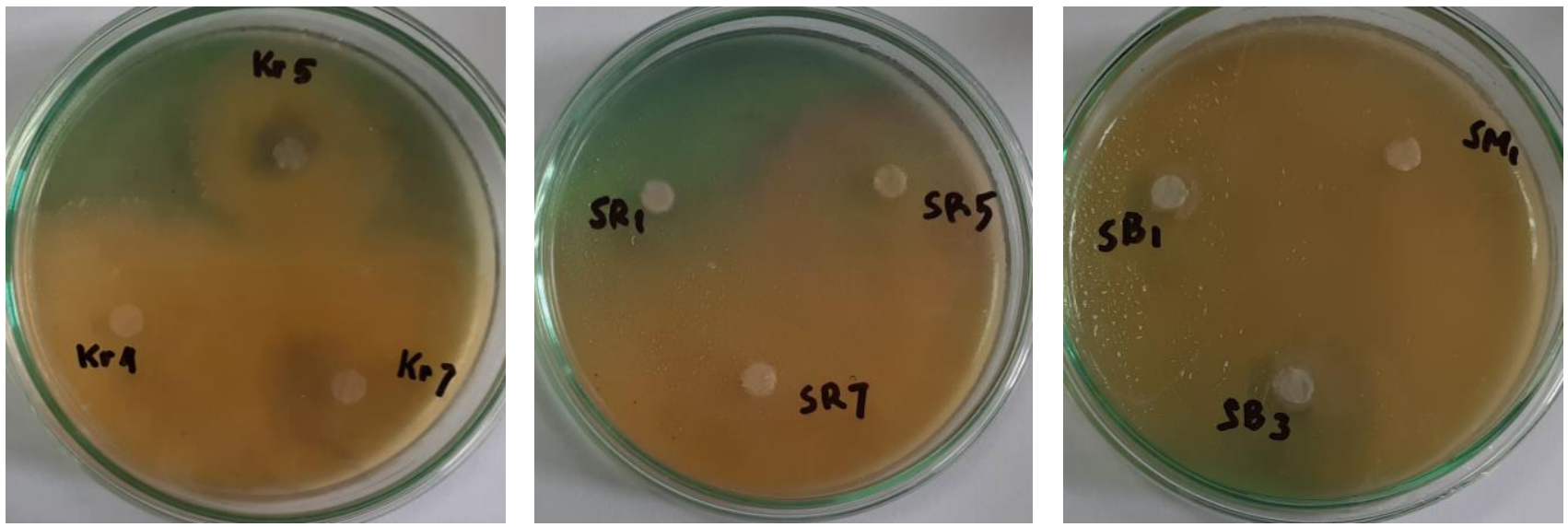

Figure 2. Siderophore production of the endophytic bacteria

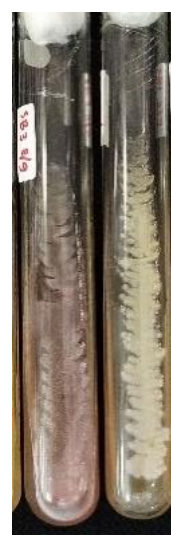

a

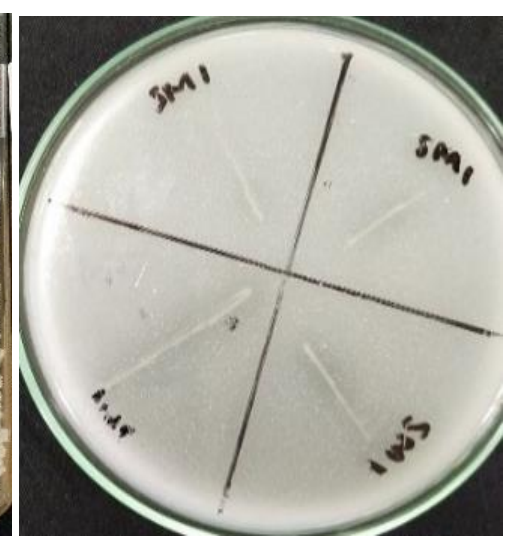

B

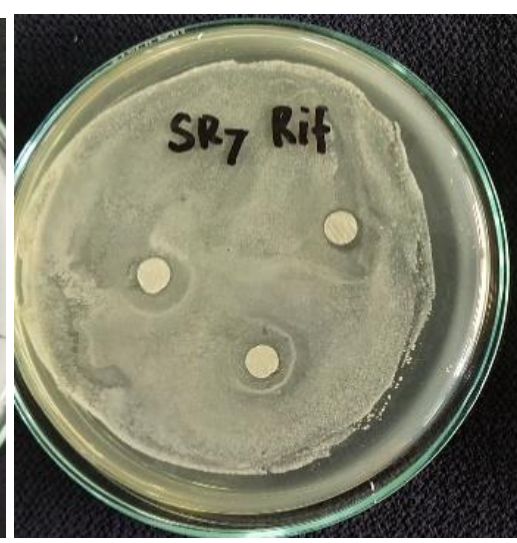

a

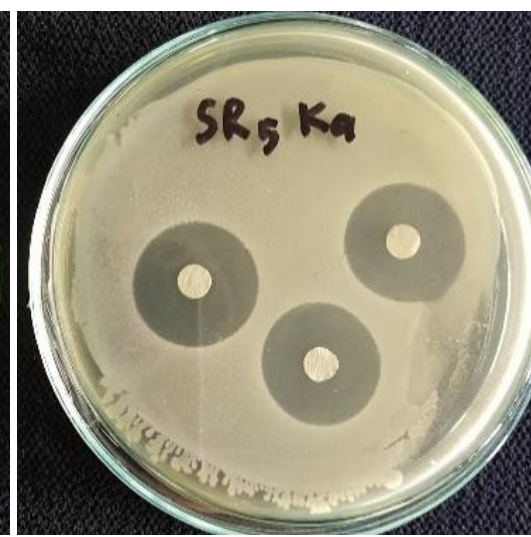

b

C

Figure 3. A. IAA production (a. produce of IAA and b. unproduce of IAA); B. Phosphate solubility; C. Resistance to antibiotics of the endophytic bacteria (a. SR7 resistance Rifampicin, and b. SR5 sensitive to Kanamicyn) 
Table 3. The component of plant growth with endophytic bacteria application

\begin{tabular}{lccc}
\hline Isolate code & $\begin{array}{c}\text { Plant } \\
\text { height }(\mathbf{c m})\end{array}$ & $\begin{array}{c}\text { Number of } \\
\text { tillers }\end{array}$ & $\begin{array}{c}\text { Number of } \\
\text { panicle/clump }\end{array}$ \\
\hline A (control) & $96.6 \mathrm{~b}$ & $13.3 \mathrm{~b}$ & 9.875 \\
B (SM1) & $101.3 \mathrm{a}$ & $12.6 \mathrm{~b}$ & 13.005 \\
C (SB1) & $98.5 \mathrm{~b}$ & $15.3 \mathrm{ab}$ & 12.125 \\
D (SB3) & $98.8 \mathrm{~b}$ & $18.3 \mathrm{a}$ & 18.875 \\
\hline
\end{tabular}

Table 4. Components of plant pathosystems against bacterial leaf blight

\begin{tabular}{lcccc}
\hline Isolate code & $\begin{array}{c}\text { Incubation } \\
\text { period (dat) }\end{array}$ & $\begin{array}{c}\text { Disease } \\
\text { intensity } \\
(\boldsymbol{\%})\end{array}$ & $\begin{array}{c}\text { Effective- } \\
\text { ness (\%) }\end{array}$ & $\begin{array}{c}\text { Infection } \\
\text { rate } \\
\text { (unit/days) }\end{array}$ \\
\hline A (control) & 24 & $23.13 \mathrm{a}$ & 0 & 0.0469 \\
B (SM1) & 30.2 & $10.17 \mathrm{~b}$ & 56.03 & 0.0435 \\
C (SB1) & 36.3 & $9.07 \mathrm{~b}$ & 60.79 & 0.0246 \\
D (SB3) & 34.2 & $9.27 \mathrm{~b}$ & 59.92 & 0.0454 \\
\hline
\end{tabular}

\section{Endophytic bacteria to promote plant growth}

Based on the result of the laboratory experiment than the endophytic bacteria selected to promote plant growth in the exfarm showed in Table 3, in which three endophytic bacteria can promote the increase plant height, the number of tiller, and the number of panicle. The SM1 (Somagede isolate) was able to increase plant height compared to other endophytic bacteria treatments and controls, while isolate Sumbang 3 (SB3) increased the number of tiller. This is in accordance with the opinion of Glick (2012) that endophytic bacteria are able to stimulate plant growth because they produce phytohormones such as IAA which can stimulate plant growth.

\section{Suppressing bacterial leaf blight by EBARr}

The observation of the pathosystem components of rice bacterial leaf blight conducted at endemic areas showed that the treatment of endophytic bacteria was different from the control (Table 4). However, between endophytic bacteria was not significantly different with control, effectiveness ranging from 56.03 to $60.79 \%$. The endophytic bacteria can delay incubation period, and suppress the infection rate. Endophytic bacteria as well as the rhizosphere bacteria are able to control bacterial disease with antibiosis mechanism as bacteriostatic which produce hydrolytic enzyme like amylase, protease, and lipase (Prihatiningsih et al. 2020b; Mugiastuti et al. 2020).

Nagendran et al. (2013) stated that endophytic bacteria were able to control bacterial leaf blight on rice with a low disease intensity of $2.80 \%$ compared to without treatment of endophytic bacteria with a disease intensity of $19.82 \%$. Four isolates, OS52, OS40, OS23, and OS53, which were identified by nucleotide sequence analysis as Enterobacter sp., B. subtilis, Bacillus sp. and Pseudomonas putida, respectively, could increase plant growth and decrease Xoo infection under greenhouse conditions. Seed treatment with these antagonists caused disease to cease in over $60 \%$ of plants. These species have been found as endophytes in rice (Yousefi et al. 2018). Endophytic bacteria are able to control the disease caused by bacteria and fungi because they produce hydrolytic enzyme as well as chitinase, protease similar to rhizospheric bacteria $B$. subtilis from potato rhizosphere (Lestari et al. 2017).

In conclusion, the conclusion based on this research showed that three endophytic bacteria are associated with rice root (EBARr) as prospectives as plant growth promoter, and biocontrol agents to bacterial leaf blight. The inhibition activity of EBARr similar to an exfarm test by suppressing the disease until $60.79 \%$ effectiveness. The rice growth enhanced by the application of EBARr with plant height and number of tiller so increase. Furthermore, endophytic bacteria was prospected to develop biofertilizer and biocontrol.

\section{ACKNOWLEDGEMENTS}

Thank you for supporting this research by DRPM Kemenristek for Riset Terapan scheme 2020 with contract number 2/SP2H/AMD/LT/DRPM/2020.

\section{REFERENCES}

Adesemoye AO, Torbert HA, Kloepper JW. 2009. Plant growthpromoting rhizobacteria allow reduced application rates of chemical fertilizer. Microb Ecol 58: 921-929. DOI: 10.1007/s00248-009-9531$\mathrm{y}$.

Ahmed E, Holmstrom SJM. 2014. Siderophores in environmental research: roles and applications. Microb Biotechnol 7: 196-208. DOI: 10.1111/1751-7915.12117.

Berg G, Krechel A, Ditz M, Sikora RA, Ulrich A, Hallmann J. 2005. Endophytic and ectophytic potato-associated bacterial communities differ in structure and antagonistic function against plant pathogenic fungi. FEMS Microbiol Ecol 51: 215-229. DOI: 10.1016/j.femsec.2004.08.006.

Christina A, Christapher V, Bhore SJ. 2013. Endophytic bacteria as a source of novel antibiotics: an overview. Pharmacogn Rev 7: 11-16. DOI: $10.4103 / 0973-7847.112833$.

Dawwam GE, Elbeltagy A, Emara HM, Abbas IH, Hassan MM. 2013. Beneficial effect of plant growth-promoting bacteria isolated from the roots of potato plant. Ann Agric Sci 58: 195-201. DOI: doi.org/10.1016/j.aoas.2013.07.007.

Djatmiko HA, Prakoso B, Prihatiningsih N. 2011. Penentuan Patotipe dan keragaman genetik Xanthomonas oryzae pv. oryzae pada tanaman padi di wilayah Karesidenan Banyumas. Jurnal Hama Penyakit Tumbuhan Tropika 11 (1): 35-46. [Indonesian]

Djatmiko HA, Prihatiningsih N, Ismangil. 2017. Pupuk Organik diperkaya Bacillus subtilis B1. Paten sederhana dengan nomor pendaftaran paten S00201707795.

Furutani A, Takaoka M, Sanada H, Noguchi Y, Oku T, Tsuno K, Ochiai H, Tsuge S. 2009. Identification of novel type III secretion effectors in Xanthomonas oryzae pv. oryzae. Mol Plant-Microb Interact 22 (1): 96-106. DOI: 10.1094/MPMI-22-1-0096.

Glick BR. 2012. Plant growth-promoting bacteria: mechanism and applications. Scientifica 2012. DOI: 10.6064/2012/963401.

Gordon RE, Haynes WC, Pang CH. 1973. The Genus Bacillus. Agriculture Research Service, United States Department of Agriculture, Washington DC.

Hamilton CE, Gundel PE, Helander M, Saikkonen K. 2012. Endophytic mediation of reactive oxygen species and antioxidant activity in plants: a review. Fungal Div 54: 1-10. DOI: doi.org/10.1007/5 13225012-0158-9. 
Hu QP, Xu JG. 2011. A Simple double-layered chrome azulor S agar (SDCASA) plate assay to optimize the production of siderophores by a potential biocontrol agent Bacillus. Afr J Microbiol Res 5 (25): 43214327. DOI: $10.5897 / A J M R 11.238$.

Kesaulya H, Baharuddin, Zakaria B, Syatrianty A, Syaiful. 2015. Isolation and physiological characterization of PGPR from potato plant rhizosphere in Medium Land of Buru Island. Procedia Food Sci 3: 190-199. DOI: doi.org/10.1016/j.profoo.2015.01.021.

Khan AA, Jilani G, Akhtar MS, Naqvi SMS, Rasheed. 2009. Phosphorus solubilizing bacteria: Occurrence, mechanisms and their role in crop production. J Agric Biol Sci 1 (1): 48-58.

Lestari P, Prihatiningsih N, Djatmiko, HA. 2017. Partial biochemical characterization of crude extract extracellular chitinase enzyme from Bacillus subtilis B298. IOP Conf Ser: Mater Sci Eng 172 (2017): 012041. DOI: 10.1088/1757-899X/172/1/012041.

Mohite B. 2013. Isolation and characterization of indole acetic acid (IAA) producing bacteria from rhizospheric soil and its effect on plant growth. J Soil Sci Plant Nutr 13 (3): 638-649. DOI: 10.4067/S071895162013005000051.

Mugiastuti E, Suprayogi, Prihatiningsih N, Soesanto L. 2020. Isolation and characterization of the endophytic bacteria, and their potential as maize disease control. Biodiversitas 21 (5): 1809-1815. DOI: 10.13057/biodiv/d210506.

Muthukumar A, Udhayakumar R, Naveenkumar R. 2017. Role of bacterial endophytes in plant disease control. In Endophytes: Crop Productivity and Protection (pp. 133-161). Springer, Cham.

Nagendran K, Karthikeyan G, Peeran MF, Raveendran M, Prabakar K, Raguchander T. 2013. Management of bacterial leaf blight disease in rice with endophytic bacteria. World Appl Sci J 28 (12): 2229-2241. DOI: 10.5829/idosi.wasj.2013.28.12.2009.

Olanrewaju OS, Glick BR, Babalola OO. 2017. Mechanisms of action of plant growth promoting bacteria. World J Microbiol Biotechnol 33: 197. DOI: $10.1007 / \mathrm{s} 11274-017-2364-9$.

Pieterse CM, Zamioudis C, Berendsen RL, Weller DM, Van Wees SC, Bakker PA. 2014. Induced systemic resistance by beneficial microbes. Annu Rev Phytopathol 52: 347-375. DOI: 10.1146/annurev-phyto-082712-102340.

Prihatiningsih N, Djatmiko HA, Lestari P. 2017. Aktivitas siderofor Bacillus subtilis sebagai pemacu pertumbuhan dan pengendali patogen tanaman terung. Jurnal Hama dan Penyakit Tumbuhan Tropika 17 (2): 170-178. [Indonesian]

Prihatiningsih N, Djatmiko HA, Lestari P. 2020a. Screening of competent rice root endophytic bacteria to promote rice growth and bacterial leaf blight disease control. Jurnal Hama dan Penyakit Tumbuhan Tropika 20 (1): 78-84. [Indonesian]

Prihatiningsih N, Arwiyanto T, Hadisutrisno B, Widada J. 2020. Characterization of Bacillus spp. from rhizosphere of potato Granola variety as an antibacterial against Ralstonia solanacearum. Biodiversitas 21 (9): 4199-4204. DOI: 10.13057/biodiv/d210934.

Reetha AK, Pavani SL, Mohan S. 2014. Hydrogen cyanide production ability by bacterial antagonist and their antibiotics inhibition potential on Macrophomina phaseolina (Tassi.) Goid. Int J Curr Microbiol Appl Sci 3 (5): 172-178.

Ryan RP, Germaine K, Franks A, Ryan DJ, Dowling DN. 2008. Bacterial endophytes: recent developments and applications. FEMS Microbiol Lett 278: 1-9. DOI: 10.1111/j.1574-6968.2007.00918.x.

Sarra S, Diarra L, Dembele M, Coulibaly MM, Sese Y. 2010. Characterization of bacterial leaf blight epidemic in the Office du Niger (Mali) and search for a sustainable resistance against the pathogen. Second Africa Rice Congres, Bamako Mali; Innovation and Partnerships to Realize Africa's Rice Potential.

Singh AK, Sarma Bk, Singh PK, Nandan R. 2013. Screening of rice (Oryza sativa L.) germplasms against Xanthomonas oryzae pv. oryzae. J Ecofriendly Agric 8 (1): 86-88.

Sirappa MP, Titahena MLJ. 2014. Improvement of suboptimal land productivity approach by land and plant management. J Trop Soils 19 (2): 1-11. DOI: http://dx.doi.org/10.5400/jts.2014.v19i2.99-109.

Ulloa-Ogaz AL, Muñoz-Castellanos LN, Nevárez-Moorillón GV. 2015. Biocontrol of phytopathogens: Antibiotic production as mechanism of control. Formatex 2015: 305-309.

van der Plank, JE. 1963. Plant Disease: Epidemic and Control. Academic Press, New York.

Wang M, Xing Y, Wang J, Xu Y, Wang G. 2014. The role of the chi1 gene from the endophytic bacteria Serratia proteamaculans 336x in the biological control of wheat take-all. Can J Microbiol 60: 533-540. DOI: $10.1139 / \mathrm{cjm}-2014-0212$.

Yasmin F, Othman R, Sijam K, Saad MS. 2009. Characterization of beneficial properties of plant growth-promoting rhizobacteria isolated from sweet potato rhizosphere. Afr J Microbiol Res 3 (11): 815-821. http://www.academicjournals.org/ajmr.

Yousefi H, Hassanzadeh N, Behboudi K, Firouzjahi FB. 2018. Identification and determination of characteristics of endophytes from rice plants and their role in biocontrol of bacterial blight caused by Xanthomonas oryzae pv. oryzae. Hell Plant Prot J 11: 19-33. DOI: 10.2478/hppj-2018-0003. 